TP Periodica Polytechnica Chemical Engineering

60(2), pp. 78-84, 2016

DOI: $10.3311 /$ PPch. 8101

Creative Commons Attribution (i)

RESEARCH ARTICLE

\section{Measurement of Rarely Investigated Trace Elements As, P, Sr, Zr, Rb and $Y$ in Waste Tires}

\author{
László Rácz ${ }^{1}$, Szabolcs Solti ${ }^{2}$, Iván Gresits ${ }^{3 *}$, Sándor Tölgyesi ${ }^{3}$, \\ Dóra Benedek ${ }^{3}$, Nóra Valentínyi ${ }^{3}$, Péter Mizsey ${ }^{3,4}$
}

Received 27 March 2015; accepted after revision 01 June 2015

\begin{abstract}
To exactly determine the composition of the waste tires appearing by the million tons worldwide is of outstanding importance when we are faced with the problem of reuse and recycling. This precise analysis and determination of the composing elements of used tires is the first step towards surveying the possible harmful or toxic effects on the environment and human health. The emission of elements into the atmosphere, groundwater and surface water can be related to traffic, recycling and energy production procedures. In this paper we demonstrate the results of the analysis of trace chemical elements As, $P, S r, R b, Y$, and $\mathrm{Zr}$ under 100 ppm in waste tire granules, which were carried out with non-destructive X-ray fluorescence spectrometry (XRF). According to the literature these elements were rarely analysed or detected together. Despite the low concentrations, their effect may be significant due to their large quantities.
\end{abstract}

\section{Keywords}

Waste tire, XRF, trace elements, analysis

\section{Introduction}

The number of ways to utilize renewables as energy sources, and that of processes to recycle waste materials is constantly increasing. This is partly due to the strict regulations, and may also be connected with the dependence on fossil energy sources [1]. Diverse technical solutions are constantly emerging and developed to decrease the energy demand of industrial processes $[2,3]$; to decrease waste streams and to recycle process streams [4,5]; and finally - if the production of waste at the end of the process is inevitable - to utilize the generated waste materials [6-8] irrespectively of their physical state.

However, extremely resistant and durable solid waste materials, such as waste tire, can be particularly difficult to utilize. In the European Union more than 1.43 billion tonnes of waste are produced yearly, that will probably increase further with economic growth [9]. The amount of used rubber tires in the industrially developed countries may be as much as 8 to 9 kilogrammes per capita annually. The global tire production is 1.5 billion units, while in Europe approximately 3.3 million tonnes of waste tire is produced per year [10].

One of the greatest problems with the treatment of nonbiodegradable waste is a lack of suitable regulations, beside the small number of economically viable possibilities for reuse [11]. It is a vast amount of waste material, the deposition and recycling of which must be definitely taken care of. Storage holds numerous sources of danger. If the tires catch fire, the conflagration is extremely difficult to put out because of the intensive heat and dense smoke.

Fires cause air pollution, emission of toxic substances into the atmosphere, while solid combustion products pollute the environment with various organic and inorganic compounds. Besides flammability, the highly resistant nature of rubber against physical, chemical, and biological effects make waste treatment more difficult [12]. In accordance with their function, rubber tires are manufactured to withstand rough mechanical and weather conditions - for example ozone- and remain functional among extreme light conditions and in the presence of bacteria. This capacity of high resistance, however, is one of the reasons that makes reutilization or further processing difficult [13]. 
The analysis of the elemental composition of waste tires has been investigated in the literature, although these analyses have most often focused on elements present in the highest concentrations (e.g. C, H, Zn, O, S, Si, etc.). At the same time the detection of elements in the ppm concentration range is uncertain with many analytical methods. The most frequently used techniques are the ICP, ICP-MS, ICP-AES, AES, etc. [14-18]. These methods, however, involve a sensitive, long and often complicated sample preparation procedure (digestion, acid treatment, etc.). In the case of rubber tires, sample preparation is difficult in correspondence with the resistant and durable properties of rubber material. Considering the subsequent use or recycling, determining the elemental composition of tires is of great importance. On the one hand from an environmental aspect (water, soil, air pollution); on the other hand because of the harmful effects on people coming into contact with polluted environment. Through direct reuse in harbours or as artificial reefs, harmful substances can dissolve into the seawater. Traffic caused pollution involve tire wear particles present in the atmosphere originated from the road surface, which pose a danger to human health through inhalation. Moreover in the immediate surroundings of roadways, traffic related soil pollution can be observed [19]. During the frequently applied pyrolytic utilization the polluting impact is divided between the gas and ash fractions produced in the process, as certain substances may get enriched in one product or the other.

\section{Pollution caused by rubber tires}

The elemental composition is a key feature of waste tires, which should be investigated previous to recycling. Besides natural and synthetic rubber, tires contain several additives like activators (e.g. $\mathrm{ZnO}_{2}$ ), accelerants (e.g. $\mathrm{MgO}$, fatty acids, amines), ageing retardants (e.g. metal-oxides, polychloroprene), fillers (e.g. $\mathrm{BaSO}_{4}, \mathrm{MgCO}_{3}, \mathrm{CaCO}_{3}$ ), etc. [20]. Some of these elements can have a negative effect on certain features or properties of the product with recycled rubber content, e.g. accumulated metals in ashes or caustic compounds from nonmetallic components (e.g. S, Cl, F, etc.).

Traffic related pollution has been a long disputed subject relating to climate change and air pollution. The emphasis has been put to exhaust materials and gases; however, non-exhaust emission (road dust, tire wear, break wear, etc.) has a considerable effect on air quality as well [21,22]. Particulate matter, mainly PM10 (PM with an aerodynamic diameter less than 10 $\mu \mathrm{m}$ ) and PM2.5 (PM with an aerodynamic diameter less than $2.5 \mu \mathrm{m})$, may cause respiratory diseases in humans [23,24].

Kwak et al. investigated the physical and chemical properties of traffic-caused non-exhaust particles. They compared onroad particles with ones generated in laboratory driving measurements. Chemical composition of tire wear particles (TWPs), roadway particles (RWP) and break wear particles (BWPs) were analysed. Highest amount of particles was emitted during the event of braking with significant amount of tire wear particles in this fraction. However, in their study only $\mathrm{Zn}$ was directly connected with tire wear [25].

Fukuzaki et al. also analysed roadside airborne pollution connecting certain elements with their possible sources. Among the detected elements in tire tread were $\mathrm{Zn}, \mathrm{Na}, \mathrm{Al}, \mathrm{Cl}$, $\mathrm{K}, \mathrm{Ca}, \mathrm{Ti}, \mathrm{V}, \mathrm{Mn}, \mathrm{Co}, \mathrm{Ni}, \mathrm{Br}, \mathrm{Cd}$, I and $\mathrm{Pb}$. A direct connection to tire tread was established only in the case of $\mathrm{Zn}$. Rb was considered as originating in pavement and soil in the concentration of 94 and $140 \mu \mathrm{g} / \mathrm{g}$, respectively [26].

The elemental content of coal, biomass and waste tire as raw materials as well as the effect of pyrolysis on the amount of elements were analysed by Raclavská et al. The measured elements included barium $(\mathrm{Ba})$, bromine $(\mathrm{Br})$, calcium $(\mathrm{Ca})$, chlorine $(\mathrm{Cl})$, chromium $(\mathrm{Cr})$, copper $(\mathrm{Cu})$, iron $(\mathrm{Fe})$, potassium $(\mathrm{K})$, manganese $(\mathrm{Mn})$, phosphorus $(\mathrm{P})$, lead $(\mathrm{Pb})$, rubidium (Rb), sulfur (S), silicon ( $\mathrm{Si})$, strontium (Sr), titanium (Ti), yttrium (Y), and zinc ( $\mathrm{Zn}$ ). Thermal conversion, e.g. pyrolysis processes, can have an effect on the distribution of the potentially hazardous elements in the conversion products of tires. During pyrolysis the ratio of these elements changed significantly in the pyrolytic products [27].

On the other hand, only a few papers discussed the fate of the hazardous elements (e.g. Zn) in soil, water or sediment caused by leaching [28]. Leachate derived from tire-wear particles was proven to be phytotoxic to microalgae in a concentration as low as $25 \mathrm{mg} / \mathrm{L}$ in coastal waters. Such results draw the attention to the environmental effects of certain elements making up tires [29]. Thus, in order to explore the potentially harmful environmental effects, analysing the chemical composition of used rubber tires is indispensable, justifiably including elements present in the raw material in low concentrations, based on which the potential pollutants can be identified.

In our present study, the elemental compositions of used rubber tires obtained from six different manufacturers are determined with X-ray fluorescence spectroscopy (XRF), focusing on the rarely detected trace elements of As, $\mathrm{P}, \mathrm{Sr}, \mathrm{Rb}, \mathrm{Y}$, and $\mathrm{Zr}$.

\section{Materials and methods}

A frequently used analytical method to determine the elemental composition of rubber samples is inductively coupled plasma atomic emission spectroscopy (ICP-AES) or mass spectrometry (ICP-MS). These techniques are considered accurate; however, relatively long preliminary sample preparation is needed. Samples are usually digested in a strongly acidic environment at high temperatures $\left(120-220^{\circ} \mathrm{C}\right)$.

Miskolczi et al. investigated the applicability of nonpolarized energy dispersive X-ray fluorescent spectroscopy compared to the frequently used inductively coupled atomic emission spectroscopy (ICP-AES) technique. They found that XRF was a suitable and cost-effective method to analyse rubber samples, thanks to its high accuracy, low LLD (Lowest 


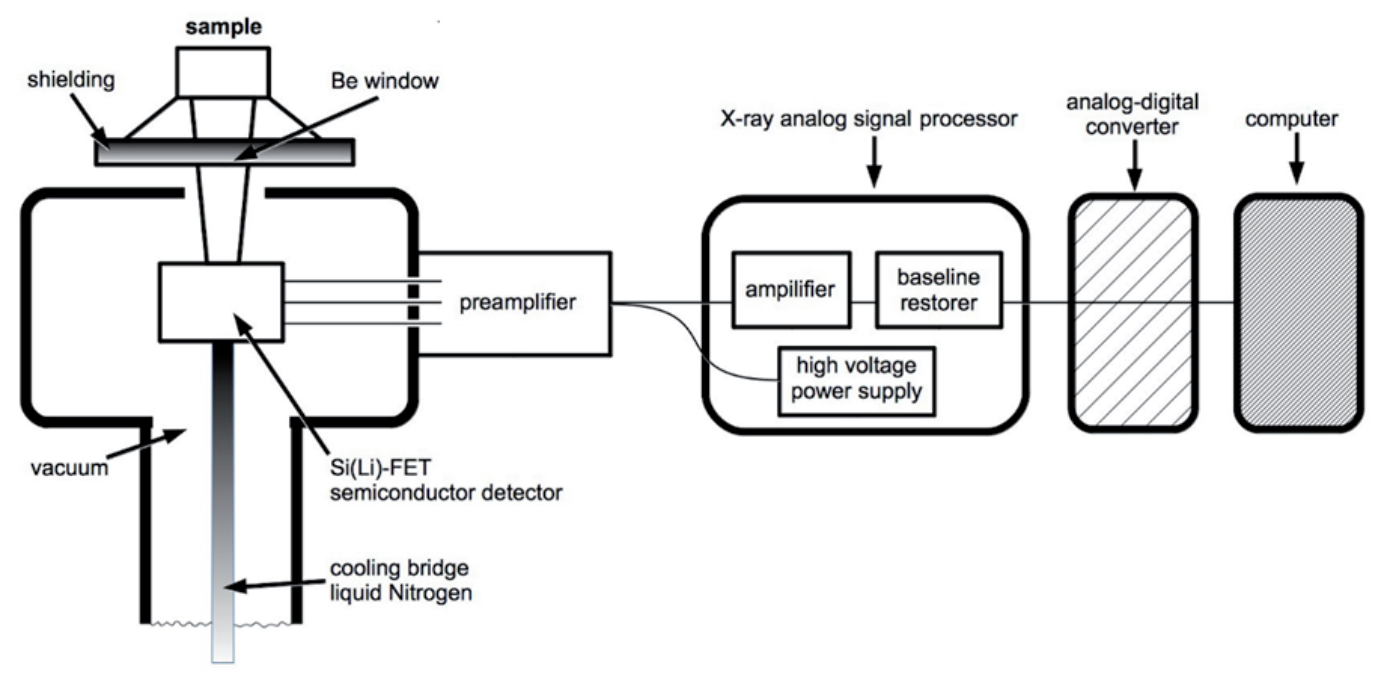

Fig. 1 The applied radioactive isotope generated energy dispersive X-ray fluorescence measuring system

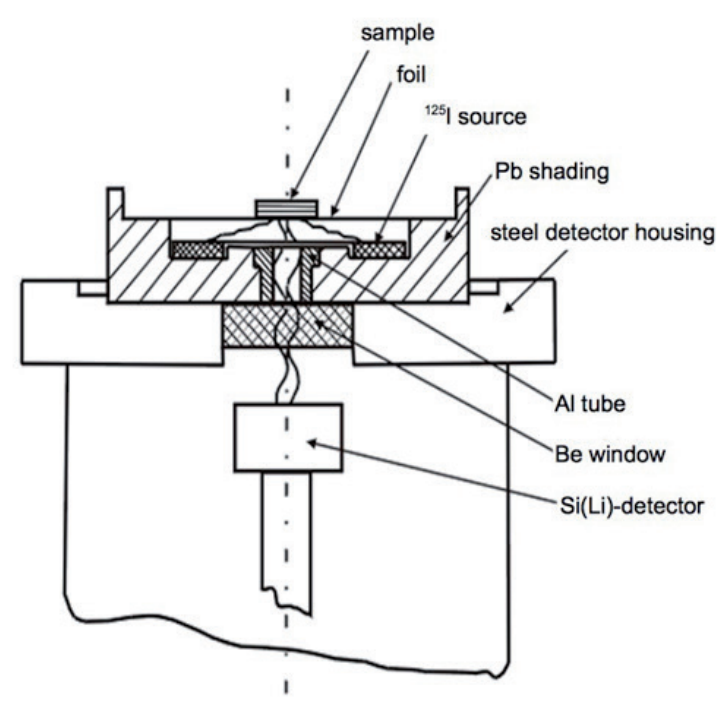

Fig. 2 The measuring unit of the X-ray fluorescence spectroscope system [31]

Limit of Detection) value and quick analysis without sample preparation [30].

In our analyses, the elemental make-up of used rubber tires was determined using isotope-generated energy dispersive $\mathrm{X}$-ray-fluorescence spectroscopy. The great advantages of XRF analysis besides almost no sample preparation, is that it is a nondestructive method avoiding contamination an loss of elements.

After the reinforcing steel wire has been removed from the tires, the samples were ground to a uniform size of $0.3 \mathrm{~mm}$. These ground tire samples were analysed with XRF.

The radioactive-isotope generated energy dispersive X-ray fluorescence measuring system applied in our studies can be seen in Fig. 1, comprising the following functional units:

- Excitation unit: For the rubber samples analysis iodine-125 isotope was used as a radiation source. The measuring unit is depicted in Fig. 2.

- Canberra SSL 80160 Si(Li) semiconductor detector with the following parameters: resolution $160 \mathrm{eV}$ at an energy level of $5.9 \mathrm{keV}$, thickness $5 \mathrm{~mm}$, surface area $80 \mathrm{~mm}^{2}$.
- Preamplifier

- Canberra DSA-100 digital spectrum processor with Genie Gamma Acquisition\&Analysis software. The applied amplitude analyser works with 2 x 8192-channels.

- Evaluating computer with software package WinAxil (CANBERRA) installed, which can be used with both the X-ray tube generated and isotope generated systems applying several determination methods.

\section{Results and Discussion}

In present study, passenger car rubber tires from six different manufacturers were investigated listed in Table 1 with their specifications. Of the 25 analysed tires, 6 orginitated from agricultural vehicles, 5 from trucks, and the remaining 14 from passenger cars.

All the analysed samples contained $\mathrm{C}, \mathrm{H}, \mathrm{Zn}, \mathrm{O}, \mathrm{Si}, \mathrm{K}, \mathrm{Cl}$, $\mathrm{Ca}$ and $\mathrm{Fe}$ in a weight percent range from 83 to $0.1 \mathrm{wt} \%$, as well as $\mathrm{Br}, \mathrm{Co}, \mathrm{Cu}, \mathrm{Cr}, \mathrm{Ni}, \mathrm{Mn}$ on a ppm concentration level in the range of 900-100. However, six trace elements (As, P, Rb, Zr, Sr and Y) were present under 100 ppm, which have been hardly mentioned in the literature. Considering the vast amount of waste tires generated on a yearly basis and their diverse recycling techniques, these trace elements can cause considerable contamination in various environmental compartments.

During our investigations the entire elemental spectra of all the samples were measured with a special attention to these elements in the lowest concentration range.

The results detailing the concentrations of these trace elements obtained through direct measurements can be seen in Table 2. In the table, the measurement results are given according to use (truck, agricultural vehicle and passenger car) and also according to the main manufacturers.

Elements detected below 100 ppm are arsenic (As), phosphorus $(\mathrm{P})$, rubidium $(\mathrm{Rb})$, zirconium $(\mathrm{Zr})$, strontium $(\mathrm{Sr})$, and yttrium (Y). Although there is some difference between the 


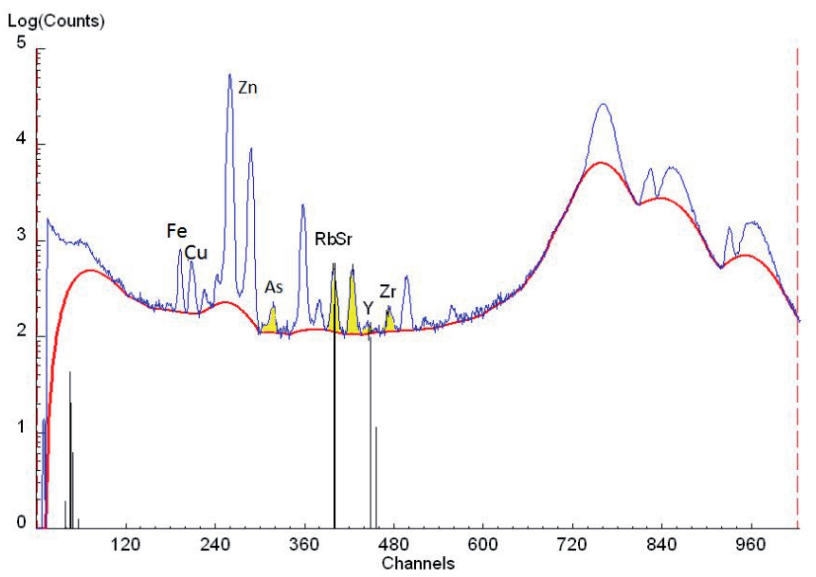

Fig. 3 Detected elemental spectrum of ' $\mathrm{P} 15 \mathrm{H}$ ' waste tire sample with the detected trace elements $\mathrm{As}, \mathrm{Rb}, \mathrm{Sr}, \mathrm{Y}$ and $\mathrm{Zr}$, marked with yellow colour.

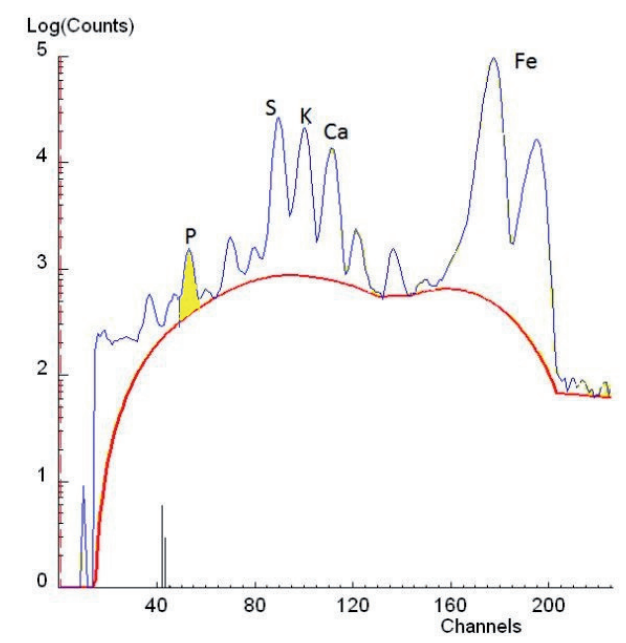

Fig. 4 Detected elemental spectrum of 'P18M' waste tire sample with the detected trace elements $\mathrm{P}$, marked with yellow colour.

products of the various manufacturers of car tires, the variance is not significant. The same slight deviation was observed in the case of elements in high concentrations. The detected XRF spectra of two randomly chosen passenger car tire samples (P15H and P18M) are depicted in Fig. 3 and 4 as an example for the detected trace component spectra. The measured concentrations of the trace elements with their variances can be

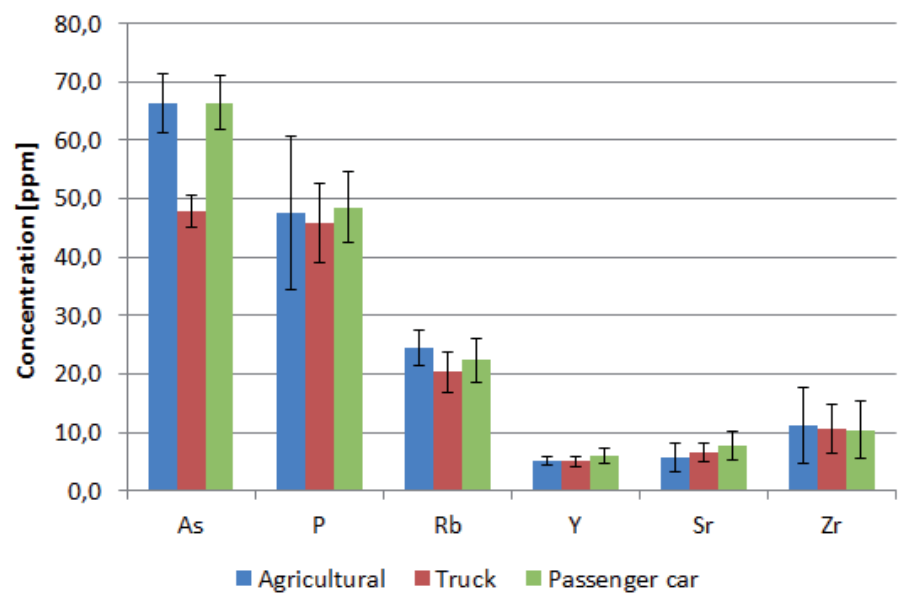

Fig. 5 The concentrations of As, P, Rb, Y, Sr, and $\mathrm{Zr}$ in tire samples of different purpose.

seen in Fig. 5. according to their application, while the different manufacturers are compared in Fig. 6.

Considering the fact, that such an extensive elemental analysis has not been present in the literature, our results cannot be compared with similar measurements. Several authors investigated mostly the composition of roadside dust and particles, from which only vague conclusions can be drawn. It can be stated though, that in the case of used tires, not only manufacture related components are present. Particles originated from the brake dust of brake shoes; dust and paint particles of road origin, as well as compounds of the catalytic converter can also adhere to the tire surface. For example Zirconium has already been shown to be present in brake dust, while Yttrium is thought to be derived from road dust [32].

Kreider et al. examined the elemental composition of the particles produced through the interaction between rubber tires and asphalt. They concluded that arsenic - which was also included in present study - had its origin in the road dust [33].

Arsenic and strontium can also be found in the brake shoes of cars so these elements may get onto the rubber tires from the brakes. During subsequent reuse or recycling these elements can appear again or they may even get enriched in the products.

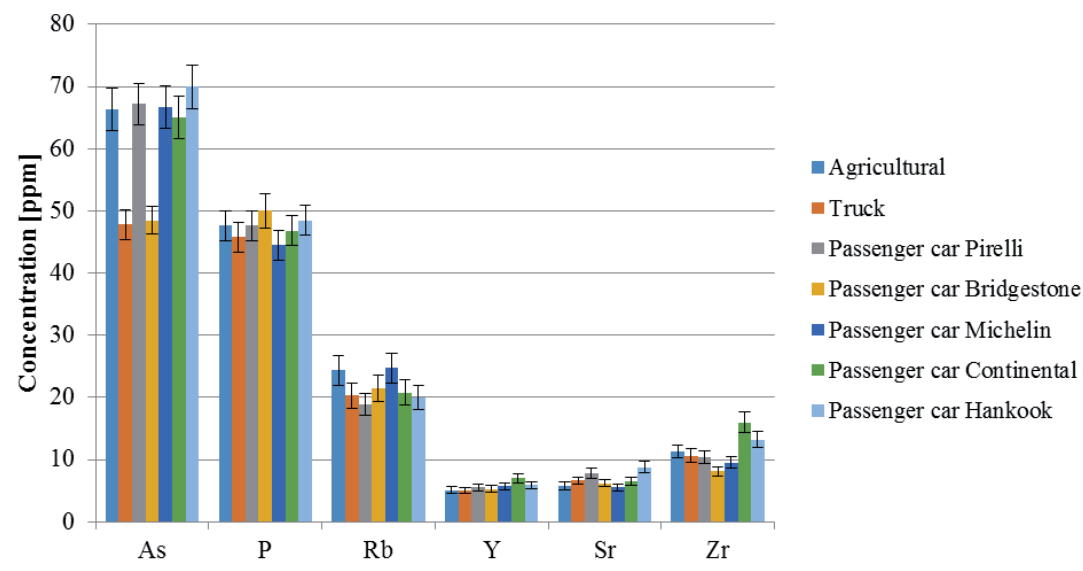

Fig. 6 The concentrations of As, P, Rb, Y, Sr, and $\mathrm{Zr}$ in tire samples according to the manufacturer. 
Table 1 Specifications of the investigated tire samples according to type and manufacturer

\begin{tabular}{|c|c|c|c|}
\hline Type & Specifications & Manufacturer & Sample ID \\
\hline Agricultural & $7.50-18$ & Pirelli & $\mathrm{A} 1 \mathrm{P}$ \\
\hline Agricultural & $14.9 / \mathrm{R} 28$ & Pirelli & $\mathrm{A} 2 \mathrm{P}$ \\
\hline Agricultural & $320 / 70$ R20 & Pirelli & A3P \\
\hline Agricultural & $650 / 85$ R38 & Continental & $\mathrm{A} 4 \mathrm{C}$ \\
\hline Agricultural & $4.00-12$ & Vredestein & $\mathrm{A} 5 \mathrm{~V}$ \\
\hline Agricultural & $520 / 85$ R38 & Continental & $\mathrm{A} 6 \mathrm{C}$ \\
\hline Passenger car & $245 / 55$ R17 & Michelin & P7M \\
\hline Passenger car & 195/50 R15 & Hankook & $\mathrm{P} 8 \mathrm{H}$ \\
\hline Passenger car & $175 / 70$ R14 & Continental & $\mathrm{P} 9 \mathrm{C}$ \\
\hline Passenger car & 215/60 R16 & Goodyear & P10G \\
\hline Passenger car & 205/55 R17 & Bridgestone & P11B \\
\hline Passenger car & $185 / 55$ R14 & Pirelli & P12P \\
\hline Passenger car & 255/40 R19 & Bridgestone & Р13B \\
\hline Passenger car & 245/35 R19 & Continental & $\mathrm{P} 14 \mathrm{C}$ \\
\hline Passenger car & 285/30 R19 & Hankook & $\mathrm{P} 15 \mathrm{H}$ \\
\hline Passenger car & 305/35 R20 & Pirelli & P16P \\
\hline Passenger car & 205/60 R16 & Goodyear & $\mathrm{P} 17 \mathrm{G}$ \\
\hline Passenger car & 225/55 R16 & Michelin & $\mathrm{P} 18 \mathrm{M}$ \\
\hline Passenger car & $275 / 40$ R18 & Michelin & P19M \\
\hline Passenger car & 205/55 R17 & Pirelli & P20P \\
\hline Truck & 235/55 R16 & Bridgestone & T21B \\
\hline Truck & $385 / 65$ R22.5 & Bridgestone & T22B \\
\hline Truck & 275/70 R22.5 & Continental & $\mathrm{T} 23 \mathrm{C}$ \\
\hline Truck & 235/65 R16 & Hankook & $\mathrm{T} 24 \mathrm{H}$ \\
\hline Truck & $315 / 80$ R22.5 & Michelin & $\mathrm{T} 25 \mathrm{M}$ \\
\hline
\end{tabular}

Table 2 Concentration of $\mathrm{As}, \mathrm{P}, \mathrm{Rb}, \mathrm{Zr}$, Sr, and $\mathrm{Y}$ in waste tires of various purpose and manufacturer. Values are demonstrated in ppm with their variances.

\begin{tabular}{|c|c|c|c|c|c|c|c|c|c|}
\hline \multirow{2}{*}{ Element } & \multirow{2}{*}{ Agricultural } & \multirow{2}{*}{ Truck } & \multirow{2}{*}{ Passenger car } & \multicolumn{6}{|c|}{ Manufacturer } \\
\hline & & & & Pirelli & Bridgestone & Michelin & Continental & Hankook & Goodyear \\
\hline As & $\begin{array}{c}66.3 \pm \\
5.0\end{array}$ & $\begin{array}{c}47.8 \pm \\
2.7\end{array}$ & $\begin{array}{c}66.4 \pm \\
4.6\end{array}$ & $\begin{array}{c}67.17 \pm \\
3.9\end{array}$ & $\begin{array}{c}48.5 \pm \\
3.2\end{array}$ & $66.75 \pm 4.8$ & $\begin{array}{c}65.0 \pm \\
6.9\end{array}$ & $70.0 \pm 11.5$ & $\begin{array}{c}63.0 \pm \\
2.8\end{array}$ \\
\hline $\mathbf{P}$ & $\begin{array}{c}47.7 \pm \\
13.2\end{array}$ & $\begin{array}{c}45.8 \pm \\
6.8\end{array}$ & $\begin{array}{c}48.6 \pm \\
6.1\end{array}$ & $\begin{array}{c}47.67 \pm \\
9.0\end{array}$ & $\begin{array}{c}50.0 \pm \\
7.1\end{array}$ & $44.5 \pm 3.2$ & $\begin{array}{c}46.8 \pm \\
12.4\end{array}$ & $48.5 \pm 6.5$ & $\begin{array}{c}52.0 \pm \\
8.5\end{array}$ \\
\hline $\mathbf{R b}$ & $\begin{array}{c}24.4 \pm \\
3.1\end{array}$ & $\begin{array}{c}20.3 \pm \\
3.4\end{array}$ & $\begin{array}{c}22.4 \pm \\
3.7\end{array}$ & $\begin{array}{c}18.9 \pm \\
3.2\end{array}$ & $\begin{array}{c}21.4 \pm \\
2.8\end{array}$ & $24.7 \pm 5.1$ & $\begin{array}{c}20.8 \pm \\
3.1\end{array}$ & $20.0 \pm 1.5$ & $\begin{array}{c}24.5 \pm \\
0.7\end{array}$ \\
\hline $\mathbf{Z r}$ & $\begin{array}{c}11.3 \pm \\
6.5\end{array}$ & $\begin{array}{c}10.6 \pm \\
1.1\end{array}$ & $\begin{array}{c}10.4 \pm \\
4.9\end{array}$ & $\begin{array}{c}10.4 \pm \\
4.2\end{array}$ & $\begin{array}{c}8.1 \pm \\
4.4\end{array}$ & $\begin{array}{c}9.5 \pm \\
3.1\end{array}$ & $\begin{array}{c}16.0 \pm \\
5.1\end{array}$ & $13.2 \pm 6.9$ & $\begin{array}{c}11.0 \pm \\
4.2\end{array}$ \\
\hline $\mathrm{Sr}$ & $\begin{array}{c}5.8 \pm \\
2.4\end{array}$ & $6.6 \pm 1.5$ & $\begin{array}{l}7.8 \pm \\
2.5\end{array}$ & $7.8 \pm 4.2$ & $\begin{array}{c}6.2 \pm \\
1.0\end{array}$ & $\begin{array}{c}5.5 \pm \\
1.3\end{array}$ & $\begin{array}{c}6.5 \pm \\
1.8\end{array}$ & $\begin{array}{c}8.8 \pm \\
1.0\end{array}$ & $\begin{array}{c}6.5 \pm \\
0.7\end{array}$ \\
\hline $\mathbf{Y}$ & $\begin{array}{c}5.1 \pm \\
0.8\end{array}$ & $5.0 \pm 0.9$ & $\begin{array}{c}6.0 \pm \\
1.4\end{array}$ & $5.5 \pm 1.7$ & $\begin{array}{c}5.3 \pm \\
1.2\end{array}$ & $\begin{array}{c}5.7 \pm \\
1.8\end{array}$ & $\begin{array}{c}7.0 \pm \\
0.4\end{array}$ & $\begin{array}{c}5.9 \pm \\
1.0\end{array}$ & $\begin{array}{c}7.0 \pm \\
0.0\end{array}$ \\
\hline
\end{tabular}


Identifying the source of the elements is, therefore, not an easy task, as the interaction of the different sources must be taken into account. Dust from the brakes, for instance, may settle on the road surface, then, it can be stirred up again. In the same way, miniscule rubber particles from the tires drift onto the roadside soil, increasing its metal content [34].

During reuse and recycling, however, the concentration in the new products, soil, water and air are more important than that their origin, thus the fate and effect of these elements should be investigated by further studies.

\section{Conclusion}

In our studies trace elements $\mathrm{As}, \mathrm{P}, \mathrm{Sr}, \mathrm{Rb}, \mathrm{Zr}$, and $\mathrm{Y}$ were detected in waste tire samples, which elements together had previously not been examined. The results show that these elements are present in similar concentrations in rubber tires of several types and origins.

In this study the suitability of the X-ray fluorescence spectrometry as analytical tool was established even in the ppm range. Applying this technique a non-destructive, quick and precise analysis of resistant rubber samples becomes possible.

Identifying the sources of the different detected elements is a complex task, especially in the case of these components of low concentration. However, if these elements get into or onto the tire, they can be a source of further problems and pollution during reuse or recycle.

As the amount of waste rubber tires is vast and, with the different recycling techniques, certain elements may get enriched in the new product, even these trace elements deserve our attention. Their impact on the environment and human health require further study.

\section{Acknowledgement}

The authors are grateful for the financial support of the projects OTKA 112699, and KMR_12-1-2012-0066 project of "Selective and complete reutilization tire of the compounds of waste tires" in the consortium of the Szelence Ltd. and the Budapest University of Technology and Economics.

\section{References}

[1] Martínez, J. D., Puy, N., Murillo, R., García, T., Navarro, M.V., Mastral, A. M. "Waste tyre pyrolysis - A review." Renewable and Sustainable Energy Reviews. 23, pp. 179-213. 2013. DOI: 10.1016/j.rser.2013.02.038

[2] Valentínyi, N., Cséfalvay, E., Mizsey, P. "Modelling of pervaporation: Parameter estimation and model development." Chemical Engineering Research and Design. 91(1), pp. 174-183. 2013. DOI: 10.1016/j.cherd.2012.07.001

[3] Valentínyi, N., Mizsey, P. "Comparison of pervaporation models with simulation of hybrid separation processes." Periodica Polytechnica Chemical Engineering. 58(1), pp. 7-14. 2014. DOI: 10.3311/PPch.7120

[4] Koczka, K., Mizsey, P. "New area for distillation: wastewater treatment." Periodica Polytechnica Chemical Engineering. 54(1), pp. 41-45. 2010. DOI: $10.3311 /$ pp.ch.2010-1.06
[5] Tóth, A. J., Gergely, F., Mizsey, P. "Physicochemical treatment of pharmaceutical process wastewater: distillation and membrane processes." Periodica Polytechnica Chemical Engineering. 55(2), pp. 59-67. 2011. DOI: 10.3311/pp.ch.2011-2.03

[6] Bóta, A., László, K., Valyon, J., Nagy, L.G., Subklew, G., Schwuger, M. J. "Activated Carbon from Waste Materials." Periodica Polytechnica Chemical Engineering. 41(1), pp. 25-39. 1997.

[7] Bóta, A., László, K., György Nagy, L., Subklew, G., Schlimper, H., Schwuger, M."Adsorbents from Waste materials." Adsorption. 3(1), pp. 81-91. 1997. DOI: 10.1007/BF01133009

[8] László, K., Bóta, A., Nagy, L.G., Cabasso, I. "Porous carbon from polymer waste materials." Colloids and Surfaces A: Physicochemical and Engineering Aspects. 151(1-2), pp. 311-320. 1999.

DOI: 10.1016/S0927-7757(98)00390-2

[9] "World Business Council for Sustainable Development, Managing Endof-Life Tires."

[10] "European Tyre \& Rubber Manufacturers' Association, End-of-life tyres management report 2011." 2011.

[11] Singh, S., Nimmo, W., Williams, P. T. "An experimental study of ash behaviour and the potential fate of $\mathrm{ZnO} / \mathrm{Zn}$ int he Co-combustion of pulverised Soutf African coal and waste tyre rubber." Fuel. 111, pp. 269-279. 2013. DOI: 10.1016/j.fuel.2013.04.026

[12] "United States Environmental Protection Agency." Rhinehart Tire Fire. 2005.

[13] Pehlken, A., Essadiqi, E. "Scrap Tire Recycling in Canada, CANMET Materials Technology Laboratory." 2005.

[14] Downard , J., Singh, A., Bullard , R., Jayarathne, T., Rathnayake, C. M., Simmons, D. L., Wels, B. R., Spak, S. N., Peters, T., Beardsley, D., Stanier, C. O., Stone, E. A. "Uncontrolled combustion of shredded tires in a landfill Part 1:Characterization of gaseous and particulate emissions." Atmospheric Environment. 104, pp. 195-204. 2015.

DOI: 10.1016/j.atmosenv.2014.12.059

[15] Gualtieri, M., Andrioletti, M., Vismara, C., Milani, M., Camatini, M. "Toxicity of tire debris leachates." Environment International. 31(5), pp. 723-730. 2005. DOI: 10.1016/j.envint.2005.02.001

[16] Lawrence, S., Sokhi, R., Ravindra, K., Mao, H., Prain, H. D., Bull, I. D., "Source apportionment of traffic emissions of particulate matter using tunnel measurements." Atmospheric Environment. 77, pp. 548-557. 2013. DOI: 10.1016/j.atmosenv.2013.03.040

[17] Querol, X., Viana, M., Alastuey, A., Amato, F., Moreno, T., Castillo, S., Pey, J., de la Rosa, J., Sánchez de la Campa, A., Artíñano, B., Salvador, P., García Dos Santos, S., Fernández-Patier, R., Moreno-Grau, S., Negral, L., Minguillón, M. C., Monfort, E., Gil, J. I., Inza, A., Ortega, L. A., Santamaría, J. M., Zabalza, J. "Source origin of trace elements in PM from regional background, urban and industrial sites of Spain." Atmospheric Environment. 41(34), pp. 7219-7231. 2007.

DOI: 10.1016/j.atmosenv.2007.05.022

[18] Sutherland, R. A., Tolosa, C. A. "Multi-element analysis of road-deposited sediment in an urban drainage basin. Honolulu." Environmental Pollution. 110(3), pp. 483-495. 2000. DOI: 10.1016/S0269-7491(99)00311-5

[19] Wiseman, C. L. S., Zereini, F., Püttmann, W. "Traffic-related trace element fate and uptake by plants cultivated in roadside soils in Toronto, Canada." Science of The Total Environment. 442, pp. 86-95. 2013. DOI: 10.1016/j.scitotenv.2012.10.051

[20] Jurkowska, B., Jurkowski, B., Nadolny, K., Krasnov, A. P., Studniev, Y. N., Pesetskii, S. S., Koval, V. N., Pinchuk, L. S., Olkhov, Y. A. "Influence of fluorine-containing lubricant on properties of NR/BR rubber." European Polymer Journal. 42(7), pp. 1676-1687. 2006. DOI: 10.1016/j.eurpolymj.2006.01.005 
[21] Dahl, A., Gharibi, A., Swietlicki, E., Gudmundsson, A., Bohgard, M., Ljungman, A., Blomqvist, G., Gustafsson, M. "Traffic-generated emissions of ultrafine particles from pavement-tire interface." Atmospheric Environment. 40(7), pp. 1314-1323. 2006.

DOI: $10.1016 /$ j.atmosenv.2005.10.029

[22] Harrison, R. M., Yin, J., Mark, D., Stedman, J., Appleby, R. S., Booker, J., Moorcroft, S. "Studies of the coarse particle $(2.5-10 \mu \mathrm{m})$ component in UK urban atmospheres." Atmospheric Environment. 35(21), pp. $3667-$ 3679. 2001. DOI: 10.1016/S1352-2310(00)00526-4

[23] Hoek, G., Brunekreef, B., Goldbohm, S., Fischer, P., van den Brandt, P. A. "Association between mortality and indicators of traffic-related air pollution in the Netherlands: a cohort study." The Lancet. 360(9341), pp. 1203-1209. 2002. DOI: 10.1016/S0140-6736(02)11280-3

[24] Pope, C. A., Burnett, R. T., Thun, M. J., Calle, E. E., Krewski, D., Ito, K., Thurston, G. D. "Lung Cancer, Cardiopulmonary Mortality, and Longterm Exposure to Fine Particulate Air Pollution." JAMA : the journal of the American Medical Association. 287(9), pp. 1132-1141. 2002.

DOI: 10.1001/jama.287.9.1132

[25] Kwak, J., Lee, S., Lee, S. "On-road and laboratory investigations on nonexhaust ultrafine particles from the interaction between the tire and road pavement under braking conditions." Atmospheric Environment. 97, pp. 195-205. 2014. DOI: 10.1016/j.atmosenv.2014.08.014

[26] Fukuzaki, N., Yanaka, T., Urushiyama, Y. "Effects of studded tires on roadside airborne dust pollution in Niigata, Japan." Atmospheric Environment (1967). 20(2), pp. 377-386. 1986. DOI: 10.1016/0004-6981(86)90041-7

[27] Raclavská, H., Corsaro, A., Juchelková, D., Sassmanová, V., Frantík, J. "Effect of temperature on the enrichment and volatility of 18 elements during pyrolysis of biomass, coal, and tires." Fuel Processing Technology. 131, pp. 330-337. 2015. DOI: 10.1016/j.fuproc.2014.12.001
[28] Degaffe, F. S., Turner, A. "Leaching of zinc from tire wear particles under simulated estuarine conditions." Chemosphere. 85(5), pp. 738-743. 2011. DOI: 10.1016/j.chemosphere.2011.06.047

[29] Turner, A., Rice, L. "Toxicity of tire wear particle leachate to the marine macroalga, Ulva lactuca." Environmental Pollution. 158(12), pp. 36503654. 2010. DOI: 10.1016/j.envpol.2010.08.001

[30] Miskolczi, N., Nagy, R., Bartha, L., Halmos, P., Fazekas, B. "Application of energy dispersive X-ray fluorescence spectrometry as multielemental analysis to determine the elemental composition of crumb rubber samples." Microchemical Journal. 88(1), pp. 14-20. 2008. DOI: 10.1016/j.microc.2007.08.007

[31] Sándor, Z., Tölgyesi, S., Gresits, I., Kratocszky, Zs. "Determination of the alloying elements in ancient silver coins by means of X-ray fluorescence method." Journal of Radioanalytical and Nuclear Chemisry. 254(2), pp. 283-288. 2002.

[32] Adachi, K., Tainosho, Y. "Characterization of heavy metal particles embedded in tire dust." Environment International. 30(8), pp. 1009-1017. 2004. DOI: 10.1016/j.envint.2004.04.004

[33] Kreider, M. L., Panko, J. M., McAtee, B. L., Sweet, L. I., Finley, B. L. "Physical and chemical characterization of tire-related particles: Comparison of particles generated using different methodologies." Science of The Total Environment. 408(3), pp. 652-659. 2010.

DOI: 10.1016/j.scitotenv.2009.10.016

[34] Thorpe, A., Harrison, R. M. "Sources and properties of non-exhaust particulate matter from road traffic: A review." Science of The Total Environment. 400(1-3). pp. 270-282. 2008. DOI: 10.1016/j.scitotenv.2008.06.007 